\title{
IMPLICATIONS OF MACRO-ECONOMIC VARIABLES FOR NATIONAL FOOD SECURITY IN NIGERIA
}

\author{
${ }^{* 1}$ Osuji, E. E., ${ }^{2}$ Tim-Ashama, A., ${ }^{3}$ Okwara, M. O., ${ }^{4}$ Effiong, J. A. L. and ${ }^{5}$ Anyanwu, U. G. \\ *IDepartment of Agricultural Economics, Michael Okpara University of Agriculture Umudike (MOUAU), Abia State, Nigeria \\ ${ }^{2}$ Department of Agricultural Science, Alvan Ikoku Federal College of Education Owerri (AIFCE), Imo State, Nigeria \\ ${ }^{3}$ Department of Agricultural Economics, Federal University of Technology Owerri (FUTO), Imo State, Nigeria \\ ${ }^{4}$ Department of Agricultural Technology, Federal Polytechnic Nekede Owerri (POLYNEK), Imo State, Nigeria.
}

*Phone: 08037351597 *Email: osujiemeka2@yahoo.com

\begin{abstract}
In recent time, the impact of macro-economic variables on agriculture has become an issue of concern in terms of securing adequate food supply for the populace. This study evaluated the implications of macro-economic variables for national food security in Nigeria. This study made use of time series data sourced from the publications of Central Bank of Nigeria Annual Reports, Statistical Bulletins and the National Bureau of Statistics spanning from 1995 to 2015. The Autoregressive Distributed Lag (ARDL) co-integration test with Error Correction Model (ECM) was adopted to substantiate the implications of these macro-economic variables. The results of the Augmented Dickey Fuller (ADF) test showed that Food security, Interest rate, Exchange rate, Net export and Government expenditures were non stationary at their respective level forms and became stationary at first difference. While Inflation and Money supply were found to be stationary at level form. ARDL bounds test for co-integration confirms the existence of long run relationship between the variables. The results of long run and short run relationships shows that Interest rate, Inflation, Government expenditures and Money supply were both significant at 5\% and 1\% levels indicating that these variables had a significant impact on food security. The estimated error correction coefficient of -0.7996 is highly significant, has the correct sign, and implies a fairly high speed of adjustment to equilibrium after a shock. However, these findings recommend farmers in Nigeria to take good advantage of the linkages between macroeconomic variables and agricultural productivity, as this useful information can assist them to boost their land productivity, hence increased food security at all times.
\end{abstract}

Keywords: error correction model, food security, implications, macro-economic variables, Nigeria

LICENSE: This work by Open Journals Nigeria is licensed and published under the Creative Commons Attribution License 4.0 International License, which permits unrestricted use, distribution, and reproduction in any medium, provided this article is duly cited.

COPYRIGHT: The Author(s) completely retain the copyright of this published article.

OPEN ACCESS: The Author(s) approves that this article remains permanently online in the open access (OA) mode.

QA: This Article is published in line with "COPE (Committee on Publication Ethics) and PIE (Publication Integrity \& Ethics)". 


\section{INTRODUCTION}

The concept of food security is examined at different levels in view of the various players in the food chain (Moses, 2006). At the household level, food security implies ensuring physical and economic access to adequate food for all household members at all times without excessive risk of losing such access (FAO, 2007). This definition entails food availability, food stability, the promotion of access and reduction in the vulnerability of household members to income and production shocks (Abalu, 1999, Davies, 2009)

Food security at the national level is conceived in terms of achieving a satisfactory balance between food demand and food supply at reasonable and stable prices (Timmer, 2004). This definition indicates a situation of developed and well-functioning food markets with no major upheavals, where adequate food is available and where most of the population have access to that food. National food security is also related to the concept of self-sufficiency. Food self-

sufficiency is generally taken to mean the extent to which a country can satisfy its food needs from its own domestic production (South centre, 2004). It is sometimes argued that the best way to increase a country's food security is to increase its level of self-sufficiency, and this idea has a certain intuitive appeal (Agba, 2006; Nielson, 2006).

Therefore, the objective of national food security would be to swell the ranks of food secure household by ensuring that all people at all times have safe and adequate access to basic food staples. According to Davies (2009) food security has been identified to incorporate food availability, food accessibility, utilization and stability of food access at all times but this concept is yet to be realized in Nigeria due to the poor agricultural outputs. Key elements of national food security for macro-economic analysis are interest rate, inflation rate, nominal exchange rate, net export, government expenditures and money supply, etc. (Shariff and Noor, 2015).

The vision of Nigeria to have physical and economic access to food on a continuous basis has continued to remain a mirage (Collar, 2009 and Amaza et al. 2009). In 2002, the food and agriculture organization (FAO) enlisted Nigeria among countries faced with serious food insecurity problems. Over 70\% percent of household across all agroecological zones in Nigeria are faced with the problem of severe food insecurity (Mariya et al. 2004). Majority of which are rural households who depend solely on agriculture for survival. However, apart from macro-economic variables, national food security is further threatened by imported food inflation, political conflicts, militancy, terrorism, war, rising oil prices, global population growth, unfavourable trade policies, climate change, environmental degradation, etc (Moses, 2006). This paper seeks to investigate the implications of macro-economic variables for national food security in Nigeria. Hence, the macro-economic variables used in this study are defined as follows;

- Food security proxy by expenditures on food production: This is the measurement of food security in terms of expenditures on food production and supply, usually in value terms.

- Interest rate: It is defined as the proportion of an amount loaned which a lender charges as interest to the borrower, normally expressed as an annual percentage. It is the rate a bank or other lender charges to borrow its money, or the rate a bank pays its savers for keeping money in an account.

- Inflation rate: It is the rate at which prices increase over time, resulting in a fall in the purchasing value of money. It is also the percent increase or decrease of prices during a specified period.

- Exchange rate: It is the price of a nation's currency in-terms of another currency. Price for which the currency of a country can be exchanged for another country's currency. 
- Net-export: It is the value of a country's total exports minus the value of its total imports. It is a measure used to calculate aggregate expenditures or the gross domestic product (GDP) of a country with an open economy.

- Government expenditures: It refers to the purchase of goods and services, which include public consumption and public investment, and transfer payments consisting of income transfers (pensions, social benefits) and capital transfer.

- Money supply: It is the total amount of money in circulation or in existence in a country. It is the entire stock of currency and other liquid instruments circulating in a country's economy as of a particular time.

\section{MATERIALS AND METHODS}

This study employed time series data sourced from the publications of Central Bank of Nigeria Annual Reports and Statistical Bulletin and the National Bureau of Statistics. The data are annuals and the sample period spanning from 1995 to 2015. The Autoregressive Distributed Lag (ARDL) cointegration test with error correction model (ECM) was adopted to substantiate the implications of macro-economic variables for national food security in Nigeria. The ARDL model lies in its flexibility that it can be applied when the variables are of a different order of integration (Pesaran and Pesaran, 1997). Food security at the micro level (individual), is measured in terms of food storage and consumption per household while at the macro level (national), food security is measured in terms of food production and supply. The later was adopted in this study.

$$
F S=f\left(I N T, I N F, E X C, N E X P, G E X P, M S, U_{t}\right)
$$

Where:

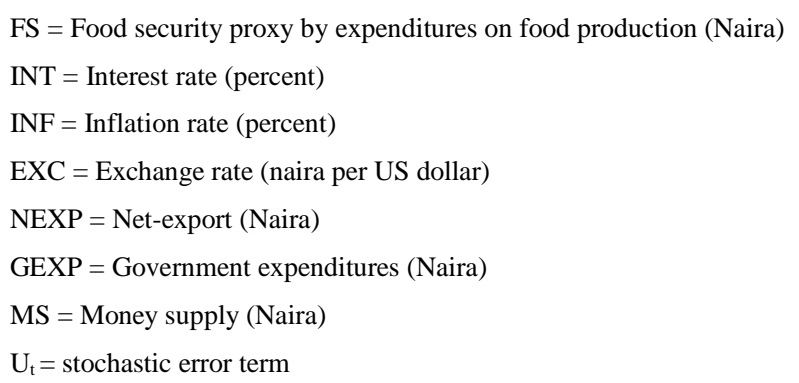

The choice of these macro-economic variables is based on economic theory since these variables make up the Monetary, Fiscal and Exchange Policies. Transforming the variables in equation (1) into natural logarithms, thus:

$$
\begin{aligned}
& \mathrm{LnFS}_{\mathrm{t}}=\beta_{0}+\beta_{1} \mathrm{LnINT}_{\mathrm{t}}+\beta_{2} \mathrm{LnINF}_{\mathrm{t}}+\beta_{3} \mathrm{LnEXC}_{\mathrm{t}}+\beta_{4} \mathrm{LnNEXP}_{\mathrm{t}}+\beta_{5} \operatorname{LnGEXP}_{\mathrm{t}}+ \\
& \beta_{6} \mathrm{LnMS}_{\mathrm{t}}+\mathrm{U}_{\mathrm{t}}
\end{aligned}
$$

Following Pesaran et al. (2001), the ARDL model specification of equation (2) is expressed as unrestricted error correction model (UECM) to test for cointegration between the variables under study, this is specified as follows: 


$$
\begin{aligned}
& \Delta \operatorname{LnFS}_{\mathrm{t}}=\varphi_{0}+\sum_{i=0}^{p} \varphi_{1} \Delta \operatorname{LnFS}_{\mathrm{t}-\mathrm{i}}+\sum_{i=0}^{p} \varphi_{2} \Delta \operatorname{LnINT}_{\mathrm{t}-\mathrm{i}}+\sum_{i=0}^{p} \varphi_{3} \Delta \mathrm{LnINF}_{\mathrm{t}-\mathrm{i}}+\sum_{i=0}^{p} \varphi_{4} \Delta \mathrm{LnEXC}_{\mathrm{t}-\mathrm{i}}+ \\
& \sum_{i=0}^{p} \varphi_{5} \Delta \operatorname{LnNEXP}_{\mathrm{t}-\mathrm{I}}+\sum_{i=0}^{p} \varphi_{6} \Delta \operatorname{LnGEXP}_{\mathrm{t}-\mathrm{i}}+\sum_{i=0}^{p} \varphi_{7} \Delta \mathrm{LnMS}_{\mathrm{t}-\mathrm{i}}+\beta_{1} \mathrm{LnFS}_{\mathrm{t}-1}+\beta_{2} \mathrm{LnINT}_{\mathrm{t}-1}+\beta_{3} \\
& \mathrm{LnINF}_{\mathrm{t}-1}+\beta_{4} \operatorname{LnEXC}_{\mathrm{t}-1}+\beta_{5} \operatorname{LnNEXP}_{\mathrm{t}-1}+\beta_{6} \mathrm{LnGEXP}_{\mathrm{t}-1}+\beta_{7} \mathrm{LnMS}_{\mathrm{t}-1}+\mathrm{U}_{\mathrm{t}}
\end{aligned}
$$

Once cointegration is established, the long run relationship is estimated using the conditional ARDL model specified as:

$$
\begin{aligned}
& \operatorname{LnFS}_{\mathrm{t}}=\varphi_{0}+\beta_{1} \operatorname{LnFS}_{\mathrm{t}-1}+\beta_{2} \operatorname{LnINT}_{\mathrm{t}-1}+\beta_{3} \mathrm{LnINF}_{\mathrm{t}-1}+\beta_{4} \operatorname{LnEXC}_{\mathrm{t}-1}+\beta_{5} \operatorname{LnNEXP}_{\mathrm{t}-1}+ \\
& \beta_{6} \mathrm{LnGEXP}_{\mathrm{t}-1}+\beta_{7} \operatorname{LnMS}_{\mathrm{t}-1}+\mathrm{U}_{\mathrm{t}}
\end{aligned}
$$

The short run dynamic relationship is estimated using an Error Correction Model (ECM) specified as:

$$
\begin{aligned}
& \Delta \mathrm{LnFS}_{\mathrm{t}}=\varphi_{0}+\sum_{\mathrm{i}=0}^{p} \varphi_{1} \Delta \mathrm{LnFS}_{\mathrm{t}-\mathrm{i}}+\sum_{i=0}^{p} \varphi_{2} \Delta \mathrm{LnINT}_{\mathrm{t}-\mathrm{i}}+\sum_{\mathrm{i}=0}^{p} \varphi_{3} \Delta \mathrm{LnINF}_{\mathrm{t}-\mathrm{i}}+\sum_{i=0}^{p} \varphi_{4} \Delta \operatorname{LnEXC}_{\mathrm{t}-\mathrm{i}} \\
& +\sum_{i=0}^{p} \varphi_{5} \Delta \mathrm{LnNEXP}_{\mathrm{t}-\mathrm{i}}+\sum_{i=0}^{p} \varphi_{6} \Delta \operatorname{LnGEXP}_{\mathrm{t}-\mathrm{i}}+\sum_{i=0}^{p} \varphi_{7} \Delta \mathrm{LnMS}_{\mathrm{t}-\mathrm{i}}+{ }_{6} \mathrm{ECM}_{\mathrm{t}-1}+\mathrm{U}_{\mathrm{t}}
\end{aligned}
$$

Where:

$\Delta=$ First difference operator

$\mathrm{Ln}=$ Natural logarithm

$\varphi_{\mathrm{o}}=$ Constant term

$\varphi_{1} \_\varphi_{7}=$ Short run elasticities (coefficients of the first-differenced explanatory variables)

$\beta_{1--} \beta_{7}=$ Long run elasticities (coefficients of the explanatory variables)

$\mathrm{ECM}_{\mathrm{t}-1}=$ Error correction term lagged for one period

$\zeta=$ Speed of adjustment

$\mathrm{p}=$ Lag length

\section{RESULTS AND DISCUSSION}

\section{NIGERIA FOOD SECURITY IN COMPARISON WITH SELECTED COUNTRIES}

Table 1; shows that only $9 \%$ of the Nigerian population is undernourished compared to $32 \%$ for Botswana, $31 \%$ for Kenya and less than $2.5 \%$ for South Africa. However, when these are translated into absolute terms, it is observed that Nigeria has the highest number (11.4) million undernourished persons in comparison with other selected countries. The data also showed that in recent times, food production in Nigeria, witnessed $0.2 \%$ and $1.9 \%$ increases over SouthAfrica and Botswana while countries like Zambia, Uganda and Ghana have over $1.8 \%$ to $14.8 \%$ relative to Nigeria. The low mechanization of agriculture in Nigeria is evident because with only 30,000 tractors, Nigeria has less than half the number used in South Africa. 
Table 1: Description of Nigeria Food Security in Comparison with Selected Countries

\begin{tabular}{lllllll}
\hline Country & $\begin{array}{l}\text { Undernourished } \\
\text { Total Population }\end{array}$ & $\begin{array}{l}\text { Number } \\
\text { Undernourished } \\
\text { persons }\end{array}$ & $\begin{array}{l}\text { Food Production } \\
\text { index (2004) }\end{array}$ & $\begin{array}{l}\text { Use of Tractors } \\
\text { (number) }\end{array}$ & $\begin{array}{l}\text { Fertilizer } \\
\text { Application } \\
\text { nmT/ha }\end{array}$ \\
\hline Botswana & 32 & 0.6 & 104.3 & $6,000.0$ & 0.08 \\
Cote d'Ivore & 13 & 2.2 & 101.2 & $9,350.0$ & 3.43 \\
Ghana & 11 & 2.3 & 121 & $3,600.0$ & 1.36 \\
Kenya & 31 & 9.9 & 104.3 & $13,955.0$ & 2.51 \\
Nigeria & 9 & 11.4 & 106.2 & $30,000.0$ & 1.82 \\
South Africa & $<2.5$ & $<0.1$ & 106 & $63,000.0$ & 7.95 \\
Uganda & 19 & 4.8 & 109.2 & 4.700 .0 & 0.47 \\
Zambia & 46 & 5.0 & 108 & $6,000.0$ & 0.88 \\
\hline
\end{tabular}

Source: Compiled from FAOSTAT (2008)

\section{NIGERIA'S AGRICULTURE PERFORMANCE SINCE 1999}

Similarly, a looming food crisis in Nigeria can be seen in all its ramifications, judging from the performance of the Nation's Agriculture. The analysis is shown in Table 2 below. It could be deduced from the Table that the geo-political zones in Nigeria showed contrasting tendencies relative to the indicators above. However, the over dependence of Nigeria on imports as shown in the Table is out of context of food security as the low use of improved technology (Osuji, 2017) adversely affects the food production system leading to food insecurity and greater reliance on food imports. Hence, there is great need to reduce over-dependence on food imports through sound policies that will encourage domestic food production in order to attain food security.

Table 2: Performance of Nigeria's Agriculture since 1999

\begin{tabular}{llllllll}
\hline INDICATORS & NC & NE & NW & SE & SS & SW & NIGERIA \\
\hline Food security & 3 & 4 & 4 & 4 & 4 & 4 & 4 \\
Poverty status of faming & 3 & 4 & 4 & 4 & 3 & 4 & 4 \\
Agricultural export & 3 & 4 & 4 & 4 & 3 & 4 & 4 \\
$\begin{array}{l}\text { Agricultural import } \\
\text { Employment in agriculture }\end{array}$ & - & - & - & - & - & - & 6 \\
$\begin{array}{l}\text { Rate of returns to agricultural } \\
\text { enterprises }\end{array}$ & 4 & 4 & 4 & 4 & 3 & 4 & 3 \\
$\begin{array}{l}\text { Economic climate for investment in } \\
\text { agriculture }\end{array}$ & 3 & 4 & 4 & 4 & 3 & 4 & 4 \\
Bridging gender gap overall average & 3 & 4 & 4 & 4 & & & \\
\hline
\end{tabular}

NB: Relatively higher=6, much better $=5$, slightly better $=4$, about the same $=3$, worse than before $=2$, worse than before $=1$, NC $=$ North central, $\mathrm{NE}=$ North-East, NW=North-West, $\mathrm{SE}=$ South-East, SS=South-South, SW=South-West.

Source: Manyong et al. (2008), FAO, (2008) 


\section{AUGMENTED DICKEY FULLER UNIT ROOT TEST}

The unit root test was carried out using Augmented Dickey Fuller (ADF) as shown in Table 3 below. The results of the ADF test show that FS, INT, EXC, NEXP and GEXP were non stationary (integrated of order one) at their respective level forms, which shows evidence of the null hypothesis. However, the variables became stationary at first difference. INF and MS were found to be stationary (integrated of order) zero at level form, which negate the null hypothesis and substantiates the alternative. Therefore, the variables under study are not integrated of the same order and this justifies the use of this model for co-integration.

Table 3: Augmented Dickey Fuller Unit Root Test Result

\begin{tabular}{llll}
\hline Variable & ADF Statistic & Lag & Decision \\
Level & & & Non-stationary \\
LnFS & -1.975670 & 0 & Non-stationary \\
LnINT & -2.102408 & 0 & Stationary \\
LnINF & -3.735401 & 1 & Non-stationary \\
LnEXC & -3.456086 & 0 & Non-stationary \\
LnNEXP & -2.983023 & 0 & Non-stationary \\
LnGEXP & -1.747329 & 0 & Stationary \\
LnMS & -3.667803 & 1 & Stationary \\
First difference & & & Stationary \\
$\Delta$ LnFS & -6.345971 & 0 & Stationary \\
$\Delta$ LnINT & -7.453727 & 0 & Stationary \\
$\Delta$ LnEXC & -6.345713 & 0 & Stationary \\
$\Delta$ LnNEXP & -5.227136 & 1 & \\
$\Delta$ LnGEXP & -4.987434 & 0 & \\
\hline & Test critical value at 5\% significant level (-3.552214) & \\
& Sag length selection was automatic based on Schwarz Information Criterion (SIC)
\end{tabular}

\section{ARDL BOUNDS TEST FOR COINTEGRATION}

The computed F-statistics as shown in Table 4 below; is 4.63. This value is above the upper bounds of the critical value of 4.22 at $5 \%$ level of significance. This implies that there is cointegration (long run relationship) between FS, INT, INF, EXC, NEXP, GEXP and MS. Hence the null hypothesis of no cointegration between the variables is further rejected and the alternative hypothesis accepted.

Table 4: ARDL Bounds Test for Cointegration

\begin{tabular}{llll}
\hline Critical Value & Lower Bound & Upper Bound & F-Statistics \\
$1 \%$ & 3.01 & 4.96 & 4.63 \\
$5 \%$ & 2.92 & 4.22 & \\
\hline \multicolumn{3}{c}{ Source: Authors computation using E-views Software }
\end{tabular}




\section{LONG RUN RELATIONSHIP USING ARDL MODEL}

The estimated long run relationship is shown in the Table 5 below. The result shows that Interest rate has a negative relationship with food security and was highly significant at $1 \%$. This shows that there exist a negative long-run relationship between Interest rate and food security (Oyinbo and Rekwot, 2014). In other words, an increase in Interest rate about 1 percent will lead to a decrease in food security about 2.5642 percent. A rise in Interest rates would translate to higher production and marketing costs, and hence increased food prices. These would adversely affect national food supply and household food demands (Moses, 2006). An increase in real Interest rates would lead to reduction in disposable income of consumers and thereby reduce their access to food and other basic necessities of life. Muftaudeen and Hussainatu (2014) posited that an increase in the lending rate will exasperate growth in output because of its deterrence impact on loan advancement, hence making finance difficult for agricultural activities. Conversely, increase in Interest rates may encourage savings, which could promote financial intermediation for investments in agriculture.

Inflation rate is also negatively related to food security and was significant at $1 \%$ level. This implies that a percent increase in Inflation rate will lead to a decrease in food security about 1.8456 percent. A high inflation rate introduces high volatility in relative prices, making investment a risky decision. The immediate impact is a reduction in investment in critical areas of agriculture with the ultimate impact being reduction in agricultural output and accessibility of the citizens to food (Moses, 2006). High inflation rates generally hurt the poor by reducing their access to food and other primary means of sustenance. This corroborates with a priori expectations and the findings of Sunday et al. (2012). Increase in inflation will raise the price of agricultural commodities which could result in reduction in agricultural commodity demand and supply. Increase in inflation rates will raise the nominal price of agricultural inputs through its multiplier effects thereby discouraging agricultural investment. Many investigations have found that persistent rise in prices discourages investment in crops production, reduce agricultural output and consequently the objective of food security becomes threatened (Muftaudeen and Hussainatu, 2014).

The coefficient of Government expenditure is positively related to food security and also highly significant at $1 \%$ level. This indicates that there exists a positive long-run relationship between Government expenditure and food security. Hence, an increase in Government expenditure about 1 percent will lead to an increase in food security about 3.4075 percent. It is expected that Government expenditures through; proper investment in agriculture, provision of rural infrastructures such as (good roads, electricity, pipe borne water, etc), irrigation, increase in agricultural incomes and input subsidies as well as extension services all geared towards increased food security. This conforms to a priori expectations and findings of (Muftaudeen and Hussainatu, 2014). On the other hand, Moses (2006) stated that if Government expenditure in agriculture is reduced, the prospects for increased agricultural incomes, the volumes of food supplies as well as prices to producers and consumers are likely to be adversely affected, bringing about fewer opportunities and less food security for the rural as well as the urban poor.

The coefficient of money supply has a positive long run relationship with food security and is significant at $5 \%$ level. This implies that a unit increase in money supply will lead to a corresponding increase in food security. Increase in money supply in terms of increased budgetary allocations to the agricultural sector and credit supply ensures food security. Credit is required for food production and an increase in money supply would translate to higher food production and marketing costs, hence increased food security. However, it is expected that as agricultural credit increases, investment in agricultural activities will also increase and consequently improves output. 
Credit assists the farm households in the purchase of farm inputs such as fertilizer, herbicides, improved seeds and investment demand which will ultimately increase their productivity and in turn aid food security. This agrees with economic theory and the findings of Osuji (2017) and Nwaru (2004).

The coefficient of Exchange rate is negatively related to food security though not significant even at $10 \%$ probability level. All things being equal, a one percent increase in Exchange rate will lead to a decrease of about 0.8794 percent in food security (Oyakhilomen and Abdulsalam, 2013). Also the coefficient of Net export is not significant but has a positive relationship with food security implying that any unit increase in Net export is likely to increase food security in the long run (Shariff and Noor, 2015). Meanwhile, if all the variables in this model are held constant, food security is likely to be increased by 2.6673 percent.

Table 5: Estimated Long Run Relationship

\begin{tabular}{lllll}
\hline Variable & Coefficient & T-values & Std Error & Significant Levels \\
Constant & 2.6673 & 2.4356 & 1.0951 & $* *$ \\
LnINT & -2.5642 & -3.2905 & 0.7792 & $* * *$ \\
LnINF & -1.8456 & -3.7454 & 0.4927 & $* * *$ \\
LnEXC & -0.8794 & -1.2752 & 0.6896 & NS \\
LnNEX & 2.9964 & 1.0573 & 2.8340 & NS \\
LnGEX & 3.4075 & 3.8468 & 0.8858 & $* * *$ \\
LnMS & 2.6890 & 2.5467 & 1.0559 & $* *$ \\
\hline \multicolumn{5}{r}{ Source: Authors computation using E-views Software } \\
& ** and *** indicates Significance @ 5\% and 1\% respectively, NS, indicates Not Significant.
\end{tabular}

\section{ESTIMATED SHORT RUN RELATIONSHIP USING ARDL MODEL}

The estimated short run relationship is shown in Table 6 below. The results of the short run dynamic coefficients associated with the long run relationships obtained from the error correction model shows that the signs of the short run dynamic interactions are consistent with that of the long run relationship but with slight deviations. In the short run, the Net export became significant at 5\% level with Government expenditure and Money supply showing some adjustment in significant levels. The estimated error correction coefficient of -0.799 is highly significant, has the correct sign, and implies a fairly high speed of adjustment to equilibrium after a shock. Approximately $80 \%$ of disequilibria from the previous year's shock converge back to the long run equilibrium in the current year. This agrees with the findings of Oyinbo and Rekwot (2014) and Samuel et al. (2013). The result of the Diagnostic Tests; shows that $\mathrm{R}^{2}$ is 0.7902 which implies that about $79 \%$ of the total variation in food security was explained by the macroeconomic variables and ECM. The DW-statistic has a value of 1.9063 which is greater than the $\mathrm{R}^{2}$ signifying that the result is not spurious and absence of autocorrelation. The result of the LM test shows that no serial correlation exists among the explanatory variables while the ARCH test indicates absence of homoscedasticity. F-statistic was highly significant at $1 \%$ showing fitness of the model. The Cusum (cumulative sum of recursive residuals) shows no evidence of instability of the error correction model. In other words, the error correction model can be said to be stable. This also agrees with the findings of Shariff and Noor (2015). 
Table 6: Estimated Short Run Relationship

\begin{tabular}{lllll}
\hline Variable & Coefficient & T-values & Std Error & Significant Levels \\
Constant & 2.5056 & 2.3651 & 1.0594 & $* * *$ \\
$\Delta$ LnINT & -0.7845 & -3.2653 & 0.2403 & $* * *$ \\
$\Delta$ LnINF & -2.9057 & -2.8867 & 0.0066 & NS \\
$\Delta$ LnEXC & -2.5904 & -1.0997 & 0.3556 & $* *$ \\
$\Delta$ LnNEX & 1.6570 & 1.9762 & 2.8385 & $* *$ \\
$\Delta$ LnGEX & 2.7314 & 1.9905 & 1.3722 & $* * *$ \\
$\Delta$ LnMS & 2.6907 & 3.2679 & 1.8234 & $* * *$ \\
Ecm(-) & -0.7996 & -3.4869 & 0.2293 & \\
Diagnostic Tests: & & & & \\
R-Squared & 0.7902 & & & \\
DW-statistic & 1.9063 & & & \\
LM test & 2.9569 & & & \\
ARCH test & 0.0542 & & & \\
F-statistic & 3.7096 & & & \\
Cusum & Stable & & & \\
\hline
\end{tabular}

Source: Authors computation using E-views Software

** and *** indicates Significance at $5 \%$ and $1 \%$ respectively, NS, indicates Not Significant.

\section{CONCLUSION AND RECOMMENDATIONS}

In recent time, the impact of macro-economic variables on agriculture has become an issue of concern in terms of securing adequate food supply for the populace. The findings show that only $9 \%$ of the Nigerian population is undernourished compared to $32 \%$ for Botswana, $31 \%$ for Kenya and less than $2.5 \%$ for South Africa. The result of the bounds test implies that there is co-integration (long run relationship) between FS, INT, INF, EXC, NEXP, GEXP and MS. Hence, the results of long run and short run relationships shows that INT, INF, GEXP and MS were both significant at 5\% and 1\% levels indicating that these variables had a significant impact on food security. The estimated error correction coefficient of -0.7996 is highly significant, has the correct sign, and implies a fairly high speed of adjustment to equilibrium after a shock. Approximately $80 \%$ of disequilibria from the previous year's shock converge back to the long run equilibrium in the current year. However, these findings suggest that if, farmers can really understand the linkages between macroeconomic variables and agricultural productivity, food insecurity will be a thing of the past as this useful information can assist them to boost their land productivity, hence food security at all times. 


\section{REFERENCES}

Abalu, G. O. I. (1999). The attainment of food security in Nigeria: The role of resource constrained in Nigeria farmers. In O. Oluwasola (Ed.), Implications of peasant agricultural practices for environmental resources, food security and agricultural sustainable development in Nigeria: Poverty alleviation and food security in Nigeria (pp. 197-206). Ibadan, Oyo State. Offsprint Press.

Agba, A.V. (2006). An overview of the monetary targeting strategy and the need for inflation in Nigeria: Proceeding of the $5^{\text {th }}$ Annual Conference of the Research and Statistics Office, Central Bank of Nigeria, CBN: Abuja. Pp. 123-129.

Amaza, P., Abdoulaye, T., Kwaghe, P., and Tegbaru,

A. (2009). Changes in household food security and poverty in Borno State, Nigeria. Journal of food and Agriculture, 2(1): 14-36.

Collar, M.O. (2009). Food security in the rural areas of Nigeria: Issues and way forward. Journal of Agriculture and Environment, 1(1): 34-39.

Davies A.E. (2009), "Food security initiatives in Nigeria: Prospects and Challenges," Journal of Sustainable Development in Africa, 11(1): 186-202

FAO, (2002). "Comprehensive Africa Agricultural Development Programme", FAO Corporate Document Repository.

FAO, (2008). Global food security outlook: Statistical reports of Food and Agriculture Organization, FAO: Rome.

FAO, (2007). Implications of economic policy for food security: Reports of Food and Agriculture Organization, FAO: Rome.

Manyong, V. M., Ikpi, A. I., Olayemi, J. K.., Yusuf, S.A., Omonana, R., and Idachaba, F.S. (2008). Agriculture in Nigeria: Identifying opportunities for increased commercialization and investment. Journal of Agricultural sciences, 2(1): 12-22.

Mariya, B., Sanusi, A., Nokoe, R., and Hariss, E. (2004). Nigeria Food Consumption and Nutrition Survey: Reports of International Institute for Tropical Agriculture. (IITA) Ibadan. pp. 22-27.

Moses, A. (2006). Implcation of macro-economic policies for national food security in Nigeria. Proceedings of Central Bank of Nigeria, CBN: Nigeria. Pp. 214-217.

Muftaudeen, O.O., and Hussainatu, A. (2014). Macroeconomic Policy and Agricultural Output in Nigeria: Implications for Food Security. American Journal of Economics, 4(2): 99-113

Nwaru, J.C. (2004). Rural Credit Markets and Resources Use in Arable Crop Production in Imo State, Nigeria. Ph.D Thesis, Department of Agricultural Economics, Micheal Okpara University of Agriculture Umudike, Nigeria.

Nielson, P. (2006). Promoting broad-based economic growth and food Security: “A view from the European Union”, proceedings of International Food Policy Research Institute, IFPRI: Washington: D.C. 
Osuji, E. E. (2017). Impacts of sustainable soil management techniques on land productivity and poverty levels of arable crop farmers in Imo State, Nigeria: Unpublished $\mathrm{PhD}$ dissertation, Department of Agricultural Economics, Michael Okpara University of Agriculture Umudike, Nigeria.

Oyinbo, O., and Rekwot, G. Z. (2014). Agricultural Production and Economic Growth in Nigeria: Implication for Rural Poverty Alleviation. Quarterly Journal of International Agriculture, 53(3): 207-223.

Oyakhilomen, O., and Abdulsalam, Z. (2013). Agricultural Budgetary Allocation and Economic Growth in Nigeria: Implications for Agricultural Transformation in Nigeria. The Journal of Sustainable Development, 10(1):16 -27 .

Pesaran, M. H., and Pesaran, B. (1997). Working with Microfit 4.O: Interactive Econometric Analysis, Oxford, Oxford University Press.

Pesaran, M. H., Shih, Y., and Smith, R. (2001). Bounds testing approaches to the analysis of the level relationships. Journal of Applied Econometrics, 16(3): 289-326.

Samuel, A., Ebenezer, F., and Mill, X. Z. (2013). Impact of macroeconomic factors on economic growth in Ghana: A cointegration analysis. International Journal of Academic Research in Accounting, Finance and Management Sciences, 3(1): 35-45

Shariff, U., Kadir, A., and Tunggal, N. Z. (2015). The Impact of macroeconomic variables towards Agricultural Productivity in Malaysia: South East. Asia Journal of Contemporary Business, Economics and Law, 8(3): 24-27.

South Centre, (2004). Universal food security: Issues for the South, the South Centre, Geneva: Switzerland. Pp.12-19.

Sunday, B., Ini-mfon, V., Glory, E., and Daniel, E. (2012). Agricultural productivity and macro-economic variable fluctuation in Nigeria. International Journal of Economics and Finance, 4(8): 114-125

Timmer, C.P. (2004). Food security and economic growth: An Asian Perspective, Working Paper, No. 51, Centre for Global Development. 